\title{
Identification, characterization of levoglucosan kinase, and cloning and expression of levoglucosan kinase cDNA from Aspergillus niger $C B X-209$ in Escherichia coli
}

\author{
Xuliang Zhuang and Hongxun Zhang* \\ Research Center for Eco-environmental Sciences, Chinese Academy of Sciences, P.O. Box 2871, Beijing 100085, People's Republic of China
}

Received 8 February 2002, and in revised form 19 April 2002

\begin{abstract}
The first enzyme responsible for assimilating levoglucosan in Aspergillus niger $C B X$-209 was corroborated to be levoglucosan kinase that catalyzes the transfer of a phosphate group from ATP to levoglucosan to yield a glucose 6-phosphate in the presence of magnesium ion and ATP by FAB-mass spectrometric method combined with previous observations from HPLC and enzymological experiments. Levoglucosan kinase was purified to apparent homogeneity by using a combination of seven purification steps. SDSPAGE revealed a single protein band of $56 \mathrm{KDa}$. It is a monomeric enzyme and maximal enzyme activity was measured at $\mathrm{pH} 9.3$ and $30^{\circ} \mathrm{C}$. This kinase is stable below $20^{\circ} \mathrm{C}$ at a quite broad pHs ranging from 6 to 10 and levoglucosan could protect the enzyme from thermal inactivation. Exclusive substrate specificity for levoglucosan suggested that not only the structure of the intramolecular glucosidic linkage but also the configuration of the pyranose frame would be specific for recognition by levoglucosan kinase. The $K_{\mathrm{m}}$ values of this enzyme were $71.2 \mathrm{mM}$ for levoglucosan and $0.25 \mathrm{mM}$ for ATP, determined by double reciprocal plottings and ADP inhibited on the enzyme activity competitively with a Ki value of $0.20 \mathrm{mM}$. A cDNA library from $A$. niger was constructed in Escherichia coli DH5a. The library was screened for levoglucosan kinase gene on NCE selective medium and three positive recombinants were selected after a five day culture. Detection of activities of levoglucosan kinase in the cell extracts indicated that levoglucosan kinase gene $(l g k)$ was expressed by the recombinant strain of E. coli DH5 $\alpha$. C 2002 Elsevier Science (USA). All rights reserved.
\end{abstract}

Levoglucosan (1,6-anhydro- $\beta$-D-glucopyranose) $\left(\mathrm{LG}^{1}\right)$, the intramolecular glucoside between C-1 and C- 6 of $\mathrm{D}$-glucopyranose, is very scarce compared with other natural carbohydrates such as glucose, sucrose, and fructose, etc. However, this compound exists widely in nature and is generally derived from natural pyrolysis of woods. For example, Schauer et al. [1] found that levoglucosan was the major constituent in the fine particulate emissions from residential fireplace combustion of wood, contributing $18-30 \%$ of the fine particulate organic compound emissions. Since fine particulate matter emitted during wood combustion was known to con-

\footnotetext{
${ }^{*}$ Corresponding author. Fax: $+86-10-62849156$.

E-mail address: xlzhuang@mail.rcees.ac.cn (H. Zhang).

${ }^{1}$ Abbreviations used: LG, levoglucosan; LGK, levoglucosan kinase; $l g k$, levoglucosan kinase gene; FAB-MS, fast atom bombardment mass spectrometry; HPLC, high performance liquid chromatography; SDSPAGE, sodium dodecyl sulfate-polyacrylamide gel electrophoresis.
}

tribute a significant fraction of the total fine aerosol concentration in the atmosphere of both urban and rural areas [2], levoglucosan was selected to be a good candidate as a molecular tracer for wood combustion in source-apportionment studies [3]. Guillen et al. [4] also found that levoglucosan was the main component of the residues obtained from evaporation at room temperature of the remaining aqueous phase after extraction of commercial smoke flavorings with dichloromethane. In addition, levoglucosan exists in some microorganisms and even in human bodies. Pazur et al. showed that levoglucosan was formed as a by-product in the action of glucosyltransferase of Aspergillus niger with maltose [5]. Dorland et al. reported that levoglucosan was observed in approximately $20 \%$ of all human urine samples invested by thin-layer chromatography and gas chromatography-mass spectrometry, and the excretory levels varied widely from zero up to $5.3 \mathrm{mmol} / \mathrm{L}$ [6]. The compound was thought to be of exogenous origin because no 
correlation with age or disease could be established [6]. Further reports showed that levoglucosan did not induce a significant number of chromosome aberrations at doses up to $8000 \mathrm{mg} / \mathrm{ml}$ in cultured Chinese hamster v79 cells [7].

In chemical industry, Levoglucosan has been used as an intermediate for the synthesis of other carbohydrates including sugar derivatives, dextrin-like polymers, and as a research tool for determining the configuration of anomeric glucosides [8-11]. Recently, in terms of biomass utilization and because of the serious shortage of fossil fuel reserves, the production of levoglucosan from cellulosic materials as one way of saccharification has been given much attention [12]. Levoglucosan, which is the main component of the highly viscous syrup which condenses in the ice-water bath during pyrolysis of cellulose, can be used directly or indirectly as a potential feedstock to produce bulk chemicals, such as ethanol and organic acids, for the fermentation industries [1315]. Nakagawa et al. reported the itaconic acid fermentation of levoglucosan by Aspergillus terreus [14] and found that $A$. terreus could convert levoglucosan into itaconic acid in the same yield and at the same rate as glucose. Prosen et al. showed that five yeast strains tested had the ability to ferment activated charcoaltreated pyrolysis tar (containing high concentrations of levoglucosan) to ethanol [15]. Zhuang et al. [16] reported the citric acid fermentation of levoglucosan by $A$. niger and found that one of its mutant strains could produce more citric acid with increasing LG purity and had a citric acid yield of $87.5 \%$ when using purified LG as the sole carbon source in a five-day fermentation period.

With regard to enzymes involved in metabolism of LG, Kitamura et al. [17,18] found that all tested eucaryotic microorganisms capable of growing on LG could directly convert it by phosphorylation to glucose 6-phosphate with a specific kinase. But their metabolites from LG have not been reported. Very few procaryotic organisms were found to use LG. Yasui et al. [19] selected six colonies from soil that assimilated LG completely in the liquid culture and found that all of them seemed to be coryneform bacteria. Nakahara et al. [20] identified one of these colonies to be the genus $\mathrm{Ar}$ throbacter and discovered that a novel enzyme LG dehydrogenase catalyzed the dehydrogenation of LG to form 1,6-anhydro- $\beta$-D-ribo-hexopyranose-3-ulose, using $\mathrm{NAD}^{+}$as an electron acceptor. Glucose was then formed after the action of at least two other enzymes. However, no useful products have been reported by procaryotic organisms growing on LG. In our previous paper, we reported that a mutant $A$. niger $C B X-209$, which could convert LG derived from pyrolysis of wastepaper into citric acid with high yield, possessed LG kinase catalyzing the direct formation of glucose 6-phosphate from LG in the presence of ATP and $\mathrm{Mg}^{2+}$ to introduce LG into the general glycolytic pathway
[21]. LG kinase was an inductive enzyme and catalyzed a reaction similar to that of hexokinase, but a cleavage of a 1,6-intramolecular glucosidic linkage and addition of a water molecular should be involved in the reaction of glucose 6-phosphate formation from levoglucosan.

In this paper, we reported further evidence for the identification of this novel enzyme in $A$. niger by FABMS. We also reported on the purification, characterization of this special kinase, and gene cloning and expression of LG kinase gene in Escherichia coli.

\section{Materials and methods}

\section{Microorganisms, plasmids, and culture conditions}

The mutant $A$. niger $C B X-209$ was obtained by $\gamma$-ray irradiation of spores of its parent strain $C B X-2$ [16]. The strain was maintained on LG agar slant at $4{ }^{\circ} \mathrm{C}$ and subcultured every month. The medium composition per liter was: LG, $20 \mathrm{~g}$; peptone, $1 \mathrm{~g} ; \mathrm{K}_{2} \mathrm{HPO}_{4}, 1 \mathrm{~g}$; $\mathrm{MgSO}_{4} \cdot 7 \mathrm{H}_{2} \mathrm{O}, 0.5 \mathrm{~g}$; and agar, $20 \mathrm{~g}$. Large quantities of cells were obtained by culturing $C B X-209$ in $250 \mathrm{ml}$ Erlenmeyer flasks on a rotary shaker at $400 \mathrm{rpm}$ at $34^{\circ} \mathrm{C}$ for 2 days. Toward the end of $\log$ phase, cells were harvested by centrifugation $\left(4^{\circ} \mathrm{C}, 10 \mathrm{~min}\right.$ at $\left.10,000 \mathrm{~g}\right)$ and washed three times with $50 \mathrm{mM}$ extraction buffer composed of $50 \mathrm{mM}$ CHES ( $\mathrm{pH} 9.3$ ), $1 \mathrm{mM} \beta$-mercaptoethanol, $1 \mathrm{mM}$ EDTA, and $0.1 \mathrm{mM}$ phenylmethylsulfonyl fluoride. The pellet was resuspended in this buffer and stored at $-20^{\circ} \mathrm{C}$ until use. E. coli strain DH5 $\alpha$ was used for the construction of cDNA bank from $A$. niger and $l g k$ gene expression. E. coli strain was routinely grown at $37^{\circ} \mathrm{C}$ in Luria-Bertani medium with shaking or on Luria-Bertani agar, consisting of $1 \%$ tryptone, $0.5 \%$ yeast extract, $0.5 \% \mathrm{NaCl}$, and $0.1 \%$ glucose [22]. Ampicillin (Sigma, St. Louis, MO) was used at $40 \mu \mathrm{g} / \mathrm{ml}$ in culture media when required. In other experiments, selection of the positive plasmidcarrying clones which can express levoglucosan kinase activity was on NCE medium [23], in which lactose was replaced by levoglucosan and the concentration of levoglucosan was increased to $20 \mathrm{~g} / \mathrm{L}$. Plasmid pUC18 was used as a cloning vector.

\section{Enzyme assays}

LG kinase activity was assayed by measuring glucose 6-phosphate formation with the glucose 6-phosphate dehydrogenase coupling system described by Hirai et al. [24] with some modifications, i.e., the reaction mixture consisted of $100 \mathrm{mM} \mathrm{LG}, 2 \mathrm{M}$ ATP, $1 \mathrm{mM} \mathrm{NADP}{ }^{+}$ $10 \mathrm{mM} \mathrm{MgCl}_{2}$, and $1 \mathrm{U}$ glucose 6-phosphate dehydrogenase and triethanolamine buffer was replaced by $50 \mathrm{mM}$ CHES (2[N-cyclohexylamino]ethansulfonic acid) buffer ( $\mathrm{pH}$ 9.3). A non-rate-limiting amount of 
6-phosphogluconate dehydrogenase was also added to this system when crude cell extracts were used as the enzyme preparation to avoid the overestimation of the activity, caused by the additional reduction of NADP with the action of the endogenous 6-phosphogluconate dehydrogenase. Then, the value was divided by two. The increase in absorbance at $340 \mathrm{~nm}$ was continuously measured with a constant temperature cell compartment. In cases for determination of the residual activity of levoglucosan kinase, the activity was also measured by ADP formation, as described by Hirai et. al. [24] with pyruvate kinase/lactate dehydrogenase coupling system. One unit LG kinase activity was expressed as the amount of enzyme catalyzing the reduction of $1 \mu \mathrm{mol}$ $\mathrm{NADP} / \mathrm{min}$ at $30^{\circ} \mathrm{C}$ at $\mathrm{pH}$ 9.3. Protein was measured by the Coomassie brilliant blue dye binding method described by Bradford [25] with bovine serum albumin as the standard.

\section{Purification steps for LG kinase}

Step 1: Extraction of cells. About $180 \mathrm{~g}$ (wet weight) of cell pellets grown on levoglucosan medium was collected by centrifugation and washed three times with cold buffer composed of $100 \mathrm{mM}$ triethanolamine- $\mathrm{HCl} /$ $\mathrm{NaOH}(\mathrm{pH} 8.0), 1 \mathrm{mM}$ EDTA, and $1 \mathrm{mM} \beta$-mercaptoethanol $(100 \mathrm{mM}$ extraction buffer). The protease inhibitor phenylmethylsulfonyl fluoride was freshly prepared in absolute ethanol at a concentration of $30 \mathrm{mM}$ and added to the above extraction buffer to a final concentration of $0.1 \mathrm{mM}$. The washed cells were then ground in liquid nitrogen with a mortar and pestle. The extraction buffer ( $3 \mathrm{ml} / \mathrm{g}$ wet cells) was added to the frozen cell powder and the suspended powder was briefly ground again and then centrifuged at $16,000 \mathrm{~g}$ for $25 \mathrm{~min}$ to remove debris and unbroken cells. The supernatant was saved as the cell extract.

Step 2: Ammonium sulfate fractionation. Solid ammonium sulfate was added to the supernatant to $30 \%$ saturation with constant stirring. The $\mathrm{pH}$ of the solution was not adjusted. After $1 \mathrm{~h}$ of stirring, the mixture was centrifuged at $17,000 \mathrm{~g}$ for $15 \mathrm{~min}$. The precipitate was discarded. Additional solid ammonium sulfate was added to the supernatant up to $70 \%$ saturation with constant stirring for $1 \mathrm{~h}$. The precipitate was saved.

Step 3: Streptomycin sulfate fractionation. The precipitate was dissolved in a minimal volume of the extraction buffer. Then, $10 \%(\mathrm{w} / \mathrm{v})$ streptomycin sulfate solution in the same buffer was added to the solution at the rate of $1 \mathrm{mg} / \mathrm{mg}$ protein with constant stirring. After $20 \mathrm{~min}$, the solution was dialyzed against $10 \mathrm{mM}$ extraction buffer and the mixture was centrifuged at $17,000 \mathrm{~g}$ for $15 \mathrm{~min}$. The supernatant was saved.

Step 4: First ion-exchange chromatography. The supernatant after streptomycin treatment was applied to a DE-32 ion-exchanger (Whatman, UK) column
$(30 \times 2.4 \mathrm{~cm})$ equilibrated with $10 \mathrm{mM}$ triethanolamine$\mathrm{HCl} / \mathrm{NaOH}(\mathrm{pH}$ 7.9). The column was washed with $500 \mathrm{ml}$ of $50 \mathrm{mM} \mathrm{NaCl}$ in $10 \mathrm{mM}$ extraction buffer. Then, the enzyme was eluted with a linear gradient from 50 to $300 \mathrm{mM} \mathrm{NaCl}$ in the same buffer. Fractions containing the enzyme activity were concentrated and desalted to $5 \mathrm{mM}$ sodium phosphate $(\mathrm{pH}$ 7.0) with centriprep-10 tubes (Millipore, Bedford, MA).

Step 5: Hydroxyapatite column chromatography. The sample was injected onto a Bio-Scale CHT2-I hydroxyapatite column (Bio-Rad) equilibrated with $5 \mathrm{mM}$ sodium phosphate. The elution was done with a linear gradient from $5 \mathrm{mM}$ to $450 \mathrm{mM}$ of the same buffer $(\mathrm{pH}$ 7.0). The active enzyme fractions were collected and concentrated to $4 \mathrm{ml}$ with a Centriprep-10 tube.

Step 6: Second ion-exchange chromatography. The buffer for levoglucosan kinase was changed to $10 \mathrm{mM}$ triethanolamine- $\mathrm{HCl} / \mathrm{NaOH}(\mathrm{pH}$ 7.9) with Centriprep10. The sample was applied to the Express-Ion D (Whatman, UK) ion-exchanger column $(45 \times 1.9 \mathrm{~cm})$ equilibrated with $10 \mathrm{mM}$ extraction buffer. The enzyme was eluted with a linear gradient from $0 \mathrm{mM}$ up to $200 \mathrm{mM} \mathrm{NaCl}$ in the same buffer.

Step 7: Gel filtration. The activity-containing fraction from the second ion-Exchange column was pooled, concentrated, and dialyzed against $50 \mathrm{mM}$ triethanolamine- $\mathrm{HCl} / \mathrm{NaOH}$. The sample was injected onto a Sephadex G100 (Amersham Biosciences, USA) column $(80 \times 1.6 \mathrm{~cm})$ and the enzyme was then eluted with the same buffer.

\section{Analytical methods}

A KYKY-2HP-5 Fast Atom Bombardment Mass Spectrometer System (Scientific Instruments of Chinese Academy of Sciences) was used to analyze glucose 6phosphate formed from levoglucosan in the reaction with cell extracts of $A$. niger $C B X-209$. The FAB-MS was operated at an accelerating voltage of $4 \mathrm{kV}$ and fitted with a $10 \mathrm{kV}$ post-acceleration detector. Fast-atom bombardment was performed using an IonTech saddlefield FAB gun operated at $6 \mathrm{kV}$ and with Ar gas. Spectra were recorded with negative-ion detection and acquired with a scan rate of $10 \mathrm{~s} \mathrm{decade}^{-1}$ over a mass range of 100-285 Da after calibration with CsRbI. The matrices used were diglycerol and triglycerol.

Levoglucosan $(50 \mathrm{mM})$ was incubated with the crude cell extract $(1 \mathrm{ml})$ from $A$. niger $C B X-209$ in the presence of ATP $(5 \mathrm{mM})$ and $\mathrm{MgCl}_{2}(10 \mathrm{mM})$ at $\mathrm{pH} 8.0,30^{\circ} \mathrm{C}$ for $30 \mathrm{~min}$ in a total volume of $10 \mathrm{ml}$. After the complete reaction, the mixture was heated in boiling water for $5 \mathrm{~min}$ to stop the reaction. $1 \mathrm{~g}$ positive-ion exchange resin (Type: Dowex 50, Serva, Germany) was added to the mixture, gently stirred for $1 \mathrm{~h}$, and then centrifuged to remove the precipitate. The supernatant was again treated with positive-ion exchange resin to remove 
cations in the samples. The sample was saved for detection of glucose 6-phosphate by FAB-MS.

Sodium dodecyl sulfate-polyacrylamide gel electrophoresis (SDS-PAGE) was done using the method described by Laemmli on a 7.5\% gel [26]. Gels were stained for proteins with Gel Code Blue stain reagent (Pierce, Rockford, IL).

\section{$p H$ and temperature optima}

Levoglucosan kinase activity was measured at various $\mathrm{pH}$ values within the range of $4-12$ by using $50 \mathrm{mM}$ CHES buffer in a total volume of $1 \mathrm{ml}$. The reaction mixture was the same as that described above for the enzyme assay, which was conducted by using the glucose 6-phosphate dehydrogenase coupling system method. The optimum temperature for the enzyme activity was also determined at various temperatures.

\section{Determination of kinetic parameters}

The $K_{\mathrm{m}}$ was measured by assaying the enzyme at substrate concentrations ranging from 25 to $200 \mathrm{mM}$ levoglucosan. These data were fitted to the MichaelisMenton equation using Table Curve (Jandel Scientific). $K_{\mathrm{m}}$ and $V_{\max }$ values were determined in triplicate. Inhibitor analyses were performed using $200 \mathrm{mM}$ levoglucosan.

\section{Constructions of A. niger CBX-209 cDNA library}

Preparation of cytoplasmic RNA: For a standard preparation, $100 \mathrm{mg}$ of $A$. niger cells grown on levoglucosan medium was used and washed with PBS. Total RNAs were isolated by a modified acid-guanidine thiocyanate-phenol-chloroform method [27,28] using TRIZOL (BRL, MD) reagents, according to manufacturers' instructions with minor modifications. Samples were treated with RNase-free DNase (Promega, WI) to remove residual DNA contaminants.

Preparation of $m R N A$ : mRNA was separated by chromatography through oligo(dT)-cellulose (BRL, MD) $[22,37]$.

Construction of the A. niger CBX-209 cDNA library in E. coli $D H 5 \alpha$ : cDNA was synthesized by the Universal Ribo Clone cDNASynthesis System Kit (Promega, WI) [29,30]. Briefly, first-strand reverse transcription synthesis was driven by AMV (Avian Myeloblastosis Virus) Reverse Transcriptase and Random Hexameric Primers, followed directly by second-strand replacement synthesis using RNase $\mathrm{H}$ and DNA PolymeraseI. After treatment with T4 DNA polymerase to flush the ends, the double-stranded cDNA molecules were size-fractionated to eliminate small-sized cDNA, which was less than $400 \mathrm{bp}$, to ensure successful adaptor addition and cloning. The resulting cDNA preparation was then ligated by EcoRI adaptors and cloned with T4 DNA ligase (Promega) into a plasmid pUC18 (Sangon, China), which had been cut with EcoRI (BRL) and treated with alkaline phosphatase (Takara, Japan) [31]. Transformation to $E$. coli $\mathrm{DH} 5 \alpha$ was carried out by the calcium shock method described by Lederberg and Cohen $[32,38]$.

Screening of an A. niger plasmid library for levoglucosan kinase expression

To isolate cDNA fragment representing the $A$. niger $C B X$-209 levoglucosan kinase gene (lgk), transformants were selected on LB agar plates containing $40 \mu \mathrm{g}$ ampicillin $/ \mathrm{ml}$. The ampicillin-resistant $\left(\mathrm{Ap}^{\mathrm{r}}\right)$ colonies were then replicated onto NCE agar plates containing ampicillin, IPTG $(40 \mu \mathrm{g} / \mathrm{ml})$, and levoglucosan as sole carbon and energy source, and colonies that appeared after five days of culture were selected. E. coli DH5a strain containing pUC18-lgk was named E. coli LGK.

Polyacrylamide gel electrophoresis activity staining method

Escherichia coli LGK cells grown on LB medium containing $2 \%$ levoglucosan were collected by centrifugation, washed with the extraction buffer three times, resuspended by the addition of $100 \mathrm{mM}$ triethanolamine- $\mathrm{HCl} / \mathrm{NaOH}(\mathrm{pH} 8.0)$ buffer at the rate of $3 \mathrm{ml}$ per gram of wet cells, and then broken with a sonicator. The supernatant after centrifugation at 20,000 $g$ was assayed. The supernatant equivalent to $10 \mu \mathrm{g}$ protein was electrophoresed in triplet in $7.5 \%$ polyacrylamide gel at $\mathrm{pH}$ 8.0. Electrophoresis was run at $15 \mathrm{~mA} / \mathrm{cm}^{2}$ for $2 \mathrm{~h}$ at $4{ }^{\circ} \mathrm{C}$ and developed, subsequently, according to the method described by Fine et al. [33] with some modifications, in that the gel was incubated at $30^{\circ} \mathrm{C}$ for $20 \mathrm{~min}$ in the staining solution containing $100 \mathrm{mM}$ triethanolamine- $\mathrm{HCl} / \mathrm{NaOH}(\mathrm{pH}$ 8.0), $100 \mathrm{mM}$ levoglucosan, $10 \mathrm{mM} \mathrm{MgCl}_{2}, 2 \mathrm{mM}$ ATP, $1 \mathrm{mM}$ NADP, $0.2 \mathrm{mM}$ MTT (3[4,5-dimethylthiazol-2-yl]-2,5-diphenyltetrazolium bromide), $0.06 \mathrm{mM}$ phenazine methosulfate, and $1 \mathrm{U} / \mathrm{ml}$ glucose 6-phosphate dehydrogenase, and then fixed with $20 \%$ ethanol containing $7 \%$ acetic acid.

\section{Results}

Identification of levoglucosan kinase in A. niger by FAB$M S$

As described in our previous paper [21], levoglucosan hydrating activity was absent in A. niger $C B X-209$. However, direct formation of glucose 6-phosphate from levoglucosan in the presence of ATP and $\mathrm{Mg}^{2+}$ was observed by HPLC in the reaction with both cell 


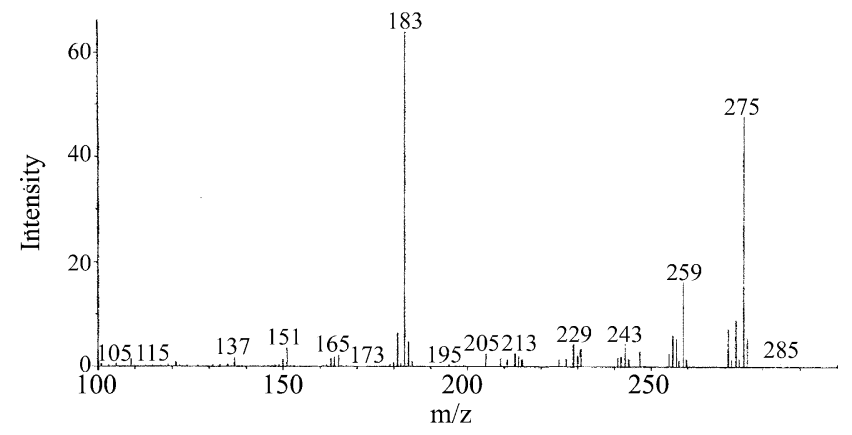

Fig. 1. Detection of the formation of glucose 6-phosphate from levoglucosan by FAB-MS (the molecule ion at $\mathrm{m} / \mathrm{z} 183,275$, and 259 stands for matrices of diglycerol and triglycerol and the formed glucose 6-phosphate, respectively).

extracts and partially purified enzyme, suggesting the existence of levoglucosan kinase in $A$. niger. In the present study, we corroborated the above reaction scheme by mass spectrometric method. When levoglucosan reacted with ATP, the derivative might either be levoglucosan phosphate without cleavage of the intramolecular glucosidic bond between C-1 and C- 6 or glucose phosphate with simultaneous cleavage of this linkage and transphosphorylation from ATP to levoglucosan. Correspondingly, the assumed compounds should have a mass of $240 \mathrm{Da}$. for levoglucosan phosphate or $258 \mathrm{Da}$. for glucose phosphate. The FAB mass spectrum is depicted in Fig. 1. The molecule ion at $\mathrm{m} / \mathrm{z}$ 259 unequivocally verified the formation of glucose phosphate from levoglucosan. The peak at $259 \mathrm{~m} / \mathrm{z}$ was the parent compound of glucose phosphate with cation $\left(\mathrm{H}^{+}\right)$. Based on mass spectra of reaction product combined with previous observations from HPLC and enzymological experiments [21], the first enzyme responsible for assimilating levoglucosan should be levoglucosan kinase that catalyzes the transfer of a phosphate group from ATP to levoglucosan to yield a glucose 6-phosphate in the presence of magnesium ions.

\section{Enzyme purification}

Levoglucosan kinase was purified from A. niger $C B X$ 209 cell extracts (Table 1). The purification scheme consisted of 7 steps and resulted in 120 -fold purification of LG kinase relative to the cell extracts.
Approximately $23.2 \%$ of LG kinase activity was recovered. The absorption spectrum of this colorless protein did not give any indications of the presence of a prosthetic group.

SDS-PAGE of the purified enzyme revealed one distinct band, corresponding to a protein with a molecular mass of $56 \mathrm{kDa}$ (Fig. 2), very approximate to that of glucokinase in A. niger (54.5 KDa) [52]. Gel filtration revealed that the molecular mass of the native enzyme is also $56 \mathrm{KDa}$, indicating that LG kinase is a monomer. The purified enzyme could be stored without apparent loss of activity at $0^{\circ} \mathrm{C}$ for 3 months.

\section{Biochemical characteristics of LG kinase}

(i) Effects of temperature on enzyme activity and stability. Under the conditions of the standard enzyme assay, LG kinase activity has a relatively low temperature optimum of $30^{\circ} \mathrm{C}$ (Fig. 3).

To evaluate the effects of temperature on enzyme stability, the kinase was incubated at various temperatures at $\mathrm{pH} 9.3$ in $50 \mathrm{mM}$ CHES buffer for $1 \mathrm{~h}$. The remaining activity was then measured at $30^{\circ} \mathrm{C}$. This enzyme was stable at temperature below $20^{\circ} \mathrm{C}$, beyond which, the enzyme was readily inactivated.

(ii) Effects of $\mathrm{pH}$ on enzyme activity and stability. It can be shown in Fig. 4 that LG kinase has an optimum $\mathrm{pH}$ of 9.3 in CHES buffer.

To evaluate the effects of $\mathrm{pH}$ on enzyme activity, the enzyme was incubated at various pHs in CHES buffer at $30^{\circ} \mathrm{C}$ for $1 \mathrm{~h}$ and then the residual activity was measured at $\mathrm{pH}$ 9.3. The enzyme was stable at a quite broad range of pHs from 6 to 10 .

(iii) Substrate preference. The kinase phosphorylating activity was detected by the measurement of ADP formation with a pyruvate kinase/lactate dehydrogenase coupling system on various sugars including levoglucosan, D-glucose, D-fructose, D-mannose, D-galactose, Dsorbose, D-xylose, arabinose, rhamnose, gluconic acid, D-ribose, D-glucosamine, raffinose, mannosan, galactosan, and maltosan. The concentration of the sugars was $200 \mathrm{mM}$. This enzyme had quite strict substrate specificity and phosphorylated levoglucosan exclusively. Other sugars and sugar derivatives at $200 \mathrm{mM}$ concentrations failed to produce ADP from ATP when

Table 1

Summary of purification of levoglucosan kinase from A. niger

\begin{tabular}{llccc}
\hline Step & Total activity $(\mathrm{U})$ & Total protein $(\mathrm{mg})$ & Specific activity $(\mathrm{U} / \mathrm{mg})$ & Overall yield $(\%)$ \\
\hline Cell extract & 594 & 1854 & 0.32 & 100 \\
Ammonium sulfate fractionation & 507 & 328.2 & 1.54 & 85.4 \\
Streptomycin sulfate treatment & 480 & 296.4 & 1.62 & 80.8 \\
First ion-exchange column & 393 & 80.1 & 4.91 & 66.2 \\
Hydroxyapatite column & 318 & 23.1 & 13.8 & 53.5 \\
Second ion-exchange column & 204 & 9.3 & 21.9 & 34.3 \\
Gel-filtration & 138 & 3.6 & 38.3 & 23.2 \\
\hline
\end{tabular}




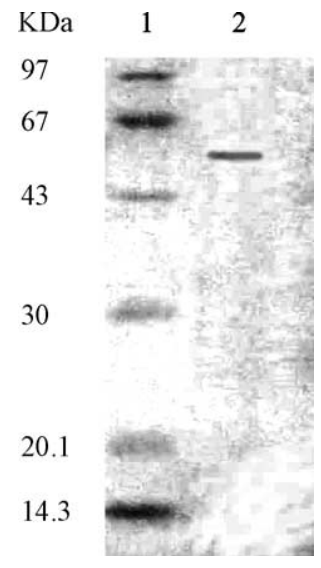

Fig. 2. SDS-PAGE of purified LG kinase from A. niger CBX-209. Lane 1, low range molecular mass standards; lane 2, $1.0 \mu \mathrm{g}$ LG kinase purified from A. niger $C B X-209$.

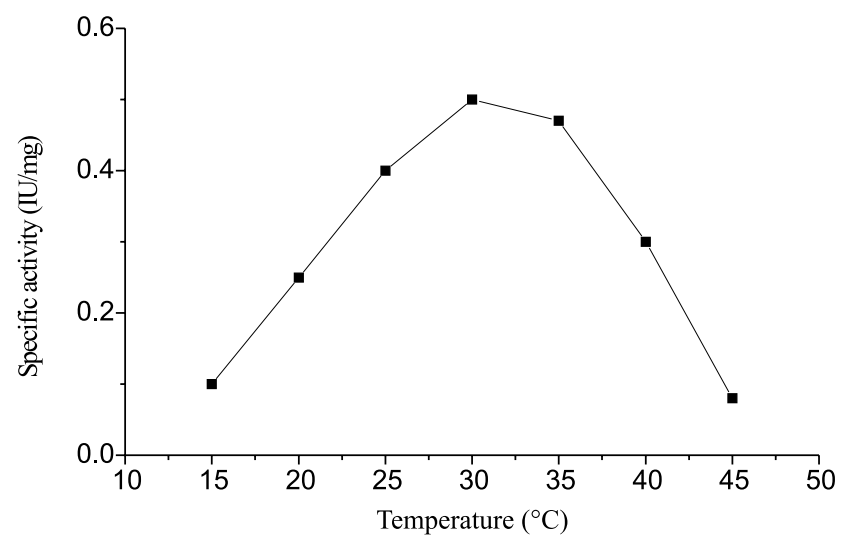

Fig. 3. Effects of temperature on the enzyme activity. The reaction was operated at various temperatures at $\mathrm{pH} 9.3$ in CHES buffer.

incubated with the enzyme. The amount of enzyme used was such that a measurable rate would have been obtained if any of these would react at a rate $0.5 \%$ of that of levoglucosan.

Just like general glucokinases from bacteria and mammals [34,35], the phosphoryl donor most effective with levoglucosan as an acceptor was ATP. Nucleoside triphosphates at $2 \mathrm{mM}$ in the presence of manganese ion gave relative rates of phosphorylation as: ATP, 100; GTP, 2; and ITP, 8. Other compounds were inactive as phosphoryl donors to levoglucosan: CTP, UTP, pyrophosphate, acetyl-P, creatine-P, ADP, glucose-1-P, fructose-6-P, and fructose-1,6-di-P.

(iv) $K_{\mathrm{m}}$ values. The $K_{\mathrm{m}}$ values of this enzyme were $71.2 \mathrm{mM}$ for levoglucosan and $0.25 \mathrm{mM}$ for ATP. To determine whether the affinity of levoglucosan kinase for levoglucosan was a function of the concentration of ATP or that of ATP a function of levoglucosan, experiments were carried out to detect the effect of levoglucosan concentration on levoglucosan kinase velocity at a number of ATP concentrations and the

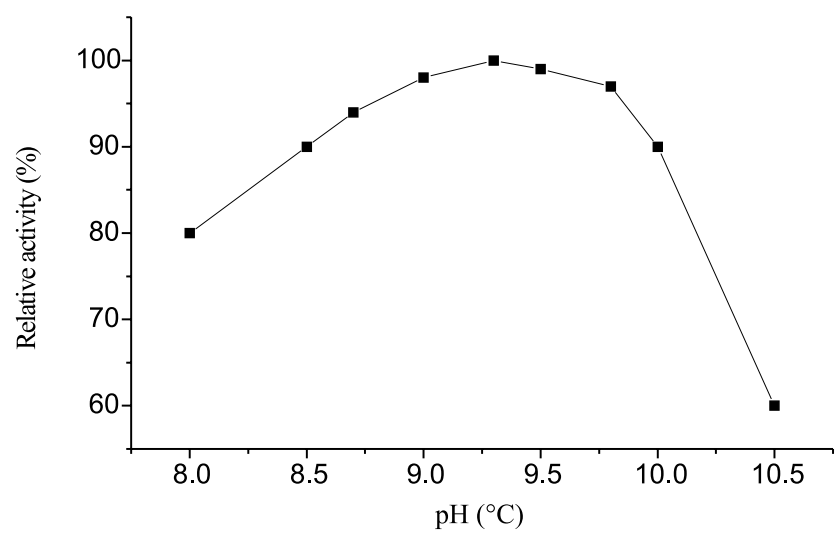

Fig. 4. Effects of $\mathrm{pH}$ on the enzyme activity. The enzyme reaction was operated in various pHs of CHES buffer and the enzyme relative activity was calculated.

effect of ATP concentration on levoglucosan kinase velocity at different concentrations of levoglucosan and the results were analyzed by double reciprocal plotting. Results showed that velocity against substrate concentrations is linear over the ranges studied and all the lines meet at a common point on both $1 /$ levoglucosan and 1/ ATP axes. This suggested that $K_{\mathrm{m}}$ values for glucose and ATP were independent of the concentrations of ATP and levoglucosan, respectively, indicating that the substrates did not compete for binding to the enzyme.

(v) Stability. The purified enzyme could be stored without apparent loss of activity at $0{ }^{\circ} \mathrm{C}$ for 3 months. However, in the frozen state, $90 \%$ of the activity was lost in $6 \mathrm{~h}$. We found that levoglucosan could protect the enzyme from thermal inactivation, since there was no significant loss of enzyme activity when it was heated at $45^{\circ} \mathrm{C}$ for $20 \mathrm{~min}$ in $50 \mathrm{mM}$ CHES buffer containing $50 \mathrm{mM}$ levoglucosan (Fig. 5). Nonetheless, enzyme protection by $\mathrm{Mg}-\mathrm{ATP}$ was negligible. It can also be seen from Fig. 5 that other sugars, such as glucose, had

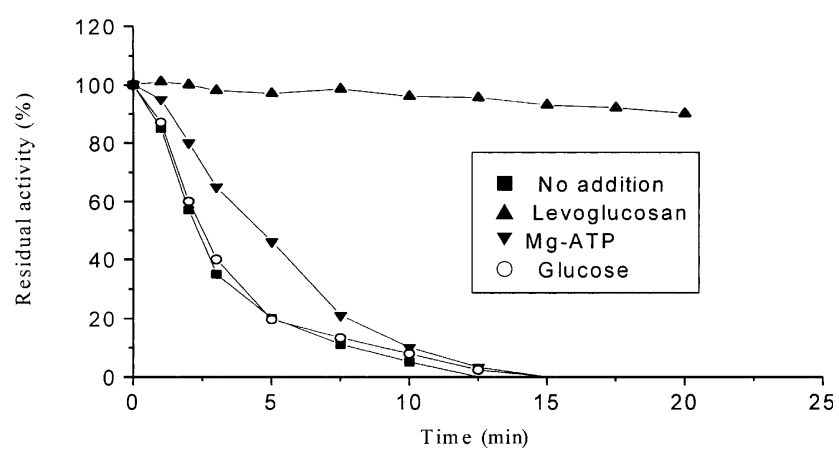

Fig. 5. Effect of levoglucosan on heat inactivation of LG kinase. LG kinase (Specific activity, $38 \mathrm{U} / \mathrm{mg}$ protein), $50 \mu \mathrm{g}$, was diluted in $50 \mathrm{mM}$ CHES buffer, pH 9.3, containing either $50 \mathrm{mM}$ levoglucosan, or glucose, or $5 \mathrm{mM} \mathrm{Mg}-\mathrm{ATP}$, or nothing, and was then heated at $45^{\circ} \mathrm{C}$ for the intervals indicated, after which reactions were quickly stopped in ice bath and then the enzyme residual activity was measured. Results are expressed as percentage of the unheated control. 
Table 2

Effect of inhibitors and metal ions on LG kinase activity

\begin{tabular}{lcc}
\hline Effector & Concentration $(\mathrm{mM})$ & Residual activity $(\%)$ \\
\hline Glucose 6-phosphate & $1^{\mathrm{a}}$ & 100 \\
Glucose 6-phosphate & $10^{\mathrm{a}}$ & 95 \\
Glucose 1-phosphate & $1^{\mathrm{b}}$ & 100 \\
Glucose 1,6-diphosphate & $1.5^{\mathrm{b}}$ & 102 \\
$\mathrm{Pi}$ & $10^{\mathrm{b}}$ & 100 \\
$\mathrm{Mg}-\mathrm{ADP}$ & $1^{\mathrm{b}}$ & 42 \\
$\mathrm{Mg}-\mathrm{ADP}$ & $2^{\mathrm{b}}$ & 28 \\
$\mathrm{Gluconate}$ 6-phosphate & $1^{\mathrm{b}}$ & 100 \\
$\mathrm{NaF}$ & $1^{\mathrm{b}}$ & 91 \\
$\mathrm{ICH} \mathrm{COOH}$ & $1^{\mathrm{b}}$ & 97 \\
$\mathrm{Dithiothreitol}$ & $1^{\mathrm{b}}$ & 100 \\
$\mathrm{HgCl}$ & $0.1^{\mathrm{b}}$ & 4 \\
$\mathrm{CoCl}_{2}$ & $1^{\mathrm{b}}$ & 18 \\
$\mathrm{CaCl}_{2}$ & $1^{\mathrm{b}}$ & 98 \\
\hline
\end{tabular}

${ }^{\mathrm{a}}$ The enzyme activity was measured by pyruvate kinase/lactate dehydrogenase coupling system

${ }^{\mathrm{b}}$ The enzyme activity was measured by glucose 6-phosphate dehydrogenase coupling system.

no effect on the protection of enzyme activity. Sodium, potasium, and calcium ions had no effect on either activity or stability of this kinase (data not shown), while glucokinase from rat liver needed potasium ions for stability [35].

(vi) Inhibitors and metal ions. A variety of enzyme inhibitors were tested for their ability to inhibit LG kinase (Table 2). The thiol reagent iodoacetate did not inhibit the enzymatic activity nor did dithiothreitol. Glucose derivatives such as glucose 1-phosphate, glucose 1,6-diphosphate, and inorganic phosphate or $\mathrm{CaCl}_{2}$ caused no significant inhibition under the tested concentrations, while $\mathrm{HgCl}_{2}$ and $\mathrm{CoCl}_{2}$ were strong inhibitors of the enzyme. LG kinase reaction product, glucose 6-phosphate also had no inhibition. On the contrary, hexokinase in $A$. niger can be strongly inhibited by physiological concentrations of the reaction product, such as trehalose 6-phosphate [50].

It can also be seen from Table 2 that low concentrations of ADP inhibit the LG kinase activity considerably. The inhibition by ADP was investigated in some detail to elucidate some aspects of the reaction mechanisms. To ensure that variations in ATP and ADP concentrations resulted in changes in their magnesium complexes, $12 \mathrm{mM} \mathrm{MgCl}$. was used in all assays. Maintaining ATP concentration at $1 \mathrm{mM}, \mathrm{Mg}^{2+}$ concentration as high as $15 \mathrm{mM}$ did not inhibit the enzyme activity. $20 \mathrm{mM} \mathrm{Mg}^{2+}$ under these conditions did not decrease the velocity significantly. Similar results were obtained at an ATP concentration equal to its $K_{\mathrm{m}}$ value. This made free ATP not to act as substrate. Fig. 6 showed the results of ADP inhibition experiments. It can be seen from the graphs (Fig. 6A) that ADP competed with ATP upon the enzyme. It can also be seen that ADP affected only the slopes with no influence on the y-intercept of these lines. In these tests, the concentration of the other substrate levoglucosan was maintained at $200 \mathrm{mM}$ and the enzyme might be saturated with this substrate. The secondary plot of slopes of these lines against the inhibitor concentration (Fig. 6B) described an approximately straight line, indicating that ADP inhibition on the enzyme was linear competitive with a $\mathrm{Ki}$ value of $0.20 \mathrm{mM}$. Unlike LG kinase, the $A$. niger glucokinase shows non-competitive inhibition by ADP towards ATP and uncompetitive inhibition by ADP towards glucose [49].

\section{Construction of cDNA bank}

A cDNA library from the fungus $A$. niger $C B X-209$, which could grow on legvoglucosan and convert it into citric acid, was constructed in E. coli DH5 $\alpha$. The minimum number of transformants needed for the cloning of a specific gene is calculated according to the following equation: $N=\ln (1-P) / \ln (1-f)$ [39], in which $P$ refers to the probability that a random cDNA fragment appears in a cDNA bank; $f$ is the size ratio of a insert fragment to the whole genome; and $N$ is the total number of transformants. Since the genome of $A$. niger is about $10,000 \mathrm{~kb}$, in a cDNA bank with an average fragment size of approx. $1.5 \mathrm{~kb}$, the total number of transformants needed is $3.07 \times 10^{4}$, with a probability of $99 \%$ of an objective insert contained in the bank. As the library we constructed contained approx. $6 \times 10^{6}$ independent $E$. coli transformants with $>90 \%$ containing an insert, it was enough for the cloning of any specific gene in $A$. niger.

\section{Isolation of positive transformants}

The library was then screened for levoglucosan kinase (LGK) gene on NCE selective medium in which levoglucosan was used as sole carbon and energy source. Since E. coli $\mathrm{DH} 5 \alpha$ or its ampicillin-resistant $\left(\mathrm{Ap}^{\mathrm{r}}\right)$ colonies $(E$. coli $\mathrm{DH} 5 \alpha$ transformed by pUC18 containing no inserts of cDNAs from $A$. niger) cannot grow 

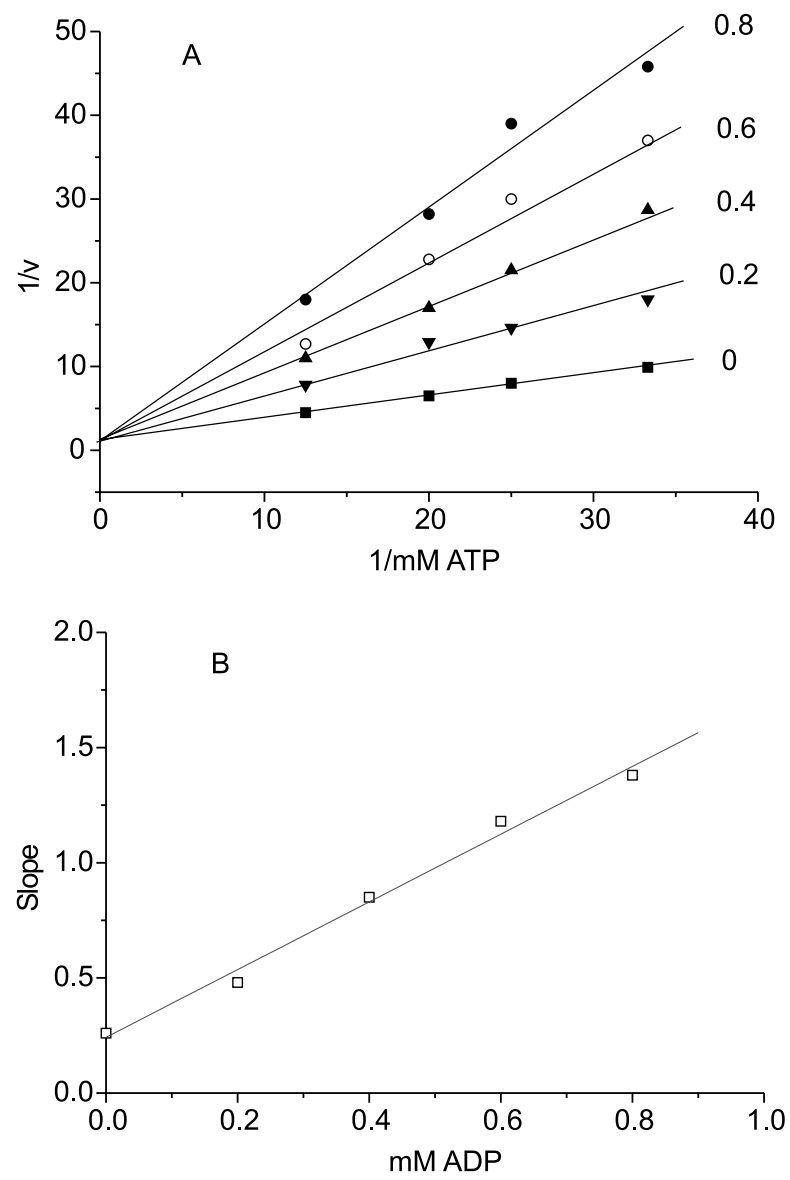

Fig. 6. Plot of the reciprocal of initial reaction velocity (v) of levoglucosan kinase against reciprocal of the millimolar concentration of ATP at various ADP concentrations indicated on the graph. Numbers against each line refer to the millimolar concentrations of ADP ( $\mathbf{\square}$, $0 \mathrm{mM}$ ADP; $\boldsymbol{\nabla}, 0.2 \mathrm{mM}$ ADP; $\boldsymbol{\Delta}, 0.4 \mathrm{mM}$ ADP; $\bigcirc, 0.6 \mathrm{mM}$ ADP; $\bullet$, $0.8 \mathrm{mM}$ ADP). All experiments were carried out in $50 \mathrm{mM}$ CHES buffer at $\mathrm{pH}$ 9.3. Levoglucosan concentration was fixed at $200 \mathrm{mM}$ on all tests. The amount of enzyme per assay was $50 \mathrm{mU}$. B is a plot of slopes of lines in A against respective ADP concentrations.

on NCE media, this method could be effective for screening genes encoding for LG kinase. Three positive recombinants were selected on this medium after a fiveday culture. One colony is shown in Fig. 7. The three positive recombinants, named E. coli LGK1, LGK2, LGK3, respectively, were recultured on NCE plates and their obvious growth was still observed.

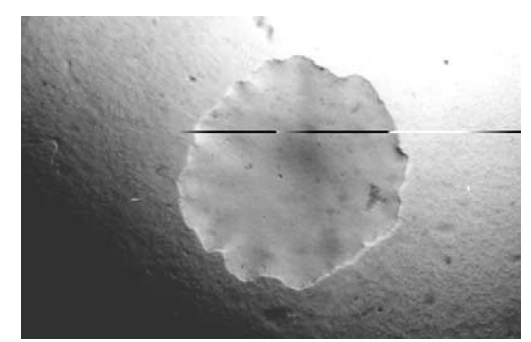

Fig. 7. Colony of E. coli LGK-2 grown on NCE plate containing levoglucosan as sole carbon source.
Detection of the activity of levoglucosan kinase in E. coli LGK1-3

Expression of levoglucosan kinase in E. coli LGK1-3 was investigated by polyacrylamide electrophoresis of the cell extracts of $E$. coli LGK1-3 incubated in media containing levoglucosan as sole carbon and energy source, followed by staining for the activity of glucose 6-phosphate production from levoglucosan by the action of this kinase. The host strain E. coli did not synthesize this special kinase. The activities of levoglucosan kinase were detected by this method in all of the extracts of the tested recombinant strains, although the quantitative tests showed that the specific activities of this enzyme in $E$. coli recombinants were only approximately one third of that in A. niger $C B X-209$. The results indicated that levoglucosan kinase gene $(l g k)$ was cloned in $E$. coli $\mathrm{DH} 5$ a.

\section{Discussion}

The invention of the fast atom bombardment (FAB) ionization technique $[36,40]$ in the early 1980 s revolutionized the mass spectrometric (MS) analysis of polar, non-volatile and thermally fragile carbohydrate molecules [41]. In the present research, we are interested in the direct detection by FAB-MS of the formation of glucose 6-phosphate from levoglucosan in A. niger $C B X-209$ and verification of the existence of levoglucosan kinase in this fungus. Although FAB-MS does not give complete structural information on the analyte in many instances, the intact molecular ions generated by $\mathrm{FAB}$ enable us to detect the formation of glucose 6-phosphate from levoglucosan in the presence of levoglucosan kinase.

This report also describes the purification, characterization, and gene cloning of LG Kinase from $A$. niger $C B X-209$. LG Kinase is induced when $A$. niger $C B X-209$ is grown on levoglucosan, reflecting its function in the levoglucosan assimilation pathways of this fungus [21]. Levoglucosan is widely distributed in nature $[1,2]$. However, little is known about the microbial degradation of this compound [17,19] and only a very few enzymes involved in microbial levoglucosan degradation have been characterized $[18,20]$, but no genes encoding for enzymes acting on levoglucosan have been studied so far.

Aspergillus niger can grow on levoglucosan medium quickly and can convert levoglucosan into citric acid with a similar yield as in the conversion from glucose [16]. Levoglucosan is directly phosphorylated to glucose 6-phosphate with a specific enzyme, levoglucosan kinase, and then metabolized through the general glycolytic pathways. However, this enzyme is unable to catalyze the reverse reaction, i.e., the anhydrolization of 
the sugar derivative, and is a monomer verified by gel filtration and SDS-PAGE experiments.

The A. niger levoglucosan kinase is very specific and catalyzes only levoglucosan according to our results. Mannosan and galactosan, which have the same intramolecular linkage as levoglucosan, could not be phosphorylated by this enzyme. On the other hand, normal sugars like glucose, galactose and mannose could not be catalyzed either. This result suggested that not only the structure of the intramolecular glucosidic linkage but also the configuration of the pyranose frame would be specific for recognition by levoglucosan kinase. In other experiments (data not shown), we also found that hexokinase and glucokinase, whether from bacteria, yeast or mammals, had no activity to phosphorylate levoglucosan. Compared with hexokinase and glucokinase, LG kinase is a new type of hexose kinase characterized by its different catalyzing steps involving cleavage of the intramolecular glucosidic linkage and the addition of a water molecule concomitantly.

The constant values of $K_{\mathrm{m}}$ for levoglucosan and ATP, irrespective of the variation in the concentrations of ATP and levoglucosan, respectively, suggest that the reaction between levoglucosan, ATP, and LG kinase takes place in a random sequence similar to that of mannokinase from a Streptomyces strain [42] in which none of the steps prior to the interconverison of enzymeATP-levoglucosan and the LG kinase-ADP-glucose-6-P is rate-controlling. This observation together with the observed inhibition data with ADP (Table 2) suggests the reaction mechanism is a rapid equilibrium random other than the ordered [43] or the "ping-pong" reaction mechanism [57,58] with a similar dead-end ternary complex between the enzyme, levoglucosan, and ADP as that described by DeWolf et al. [44]. Further experiments in substrate binding, isotope exchange, and kinetic characteristics may confirm the proposed reaction mechanism of this enzyme. Unlike other hexokinases, LG kinase was not inhibited by sugar phosphate in micromolar (physiological) concentration. Furthermore, high concentrations of glucose 6-phosphate up to $10 \mathrm{mM}$ have only slight inhibitory effects on this kinase. Although other product, ADP, is a fairly potent inhibitor, its inhibition effect could be reversed by ATP. This suggests that ATP:ADP ratio could serve as a parameter to control LG kinase in $A$. niger.

Although A. niger $C B X-209$ could convert levoglucosan into citric acid with an comparable yield as in the conversion form glucose, it had a prolonged fermentation period from 3 to 5 days to achieve this high citric acid yield [16,21]. The high $K_{\mathrm{m}}$ value $(71.2 \mathrm{mM})$ of LG kinase for levoglucosan may account for the lower assimilation and conversion rates of levoglucosan in this fungus. For general hexokinases, their $K_{\mathrm{m}}$ values ranged from only several millimolars in bacteria or fungi $[34,45]$ up to $20 \mathrm{mM}$ in mammals $[35,46]$. In the latter case, the glucokinase was suggested to regulate the blood sugar concentration with a high $K_{\mathrm{m}}[47,48]$. Compared with much lower $K_{\mathrm{m}}$ values of glucokinase $(0.063 \mathrm{mM})$ and hexokinase $(0.35 \mathrm{mM})$ for glucose in $A$. niger [49,50], $K_{\mathrm{m}}$ value of LG kinase at about $71 \mathrm{mM}$ for levoglucosan indicated that $A$. niger cells might accumulate levoglucosan in vivo at a rate higher than that of glucose to produce enough amount of glucose 6-phosphate and then convert it into high yield of citric acid. Besides this, some enzymatic properties of LG kinase different from those of other general hexose kinases may also contribute to the metabolism of levoglucosan in A. niger: Firstly, the activity of glucokinase in $A$. niger decreases rapidly at $\mathrm{pHs}$ below 7.5 ( $56 \%$ at $\mathrm{pH} 7.0$ and $17 \%$ at $\mathrm{pH}$ 6.5) and this may have important implications for the in vivo regulation of activity [49], while LG kinase in $A$. niger keeps its activity in a wide range of $\mathrm{pHs}$ from 6.0 to 10.0. Secondly, hexokinase in A. niger is strongly inhibited by physiological concentrations $(0.1-0.2 \mathrm{mM})$ of the reaction product, trehalose 6-phosphate, which may be of importance for the in vivo regulation of the enzyme, while LG kinase in $A$. niger is not inhibited by physiological concentrations of the reaction product glucose 6-phosphate up to $10 \mathrm{mM}$. These two properties of LG kinase may compensate the enzyme's catalytic efficiency.

It is surprising that, despite the extensive research on enzymes responsible for biodegradation of cellulose having been carried out for many years and their corresponding genes having been characterized and cloned, respectively [51-54], levoglucosan kinase gene has not been studied, since its discovery long time ago [55]. One reason could be levoglucosan's scarcity in its natural form [1-4]. However, because of the serious problem of limitations of fossil fuel reserves, studies on the degradation of cellulose to be singular sugar such as glucose or levogluocsan have been given much attention, as glucose or levoglucosan derived from cellulose can be easily fermented into alcohol or other useful products. Nowadays, levoglucosan can be produced in a large scale by fast pyrolysis of cellulosic materials and has become an interesting sugar candidate, which can be converted directly or indirectly into the energy sourcealcohol [15].

Fungal genes encoding for cellulases and other glucosyl hydrolases have hitherto been cloned using either differential hybridization, antibodies raised against the corresponding enzymes or hybridization with oligonucleotide probes, based on the protein sequences. All these methods are laborious, time-consuming, and require previous knowledge of the corresponding proteins. Xue et al. [56] isolated cellulase genes using enzyme assay plates from a cDNA library made in $E$. coli from the rumen fungus Neocallimastix patriciarum. With the method presented here, genes encoding for LG kinase can be directly screened on selective media containing 
levoglucosan as sole carbon and energy source. The production of $A$. niger LG kinase in $E$. coli in active form is successful and, thus, cloning of LG kinase gene by expression in $E$. coli is applicable. This method might also be useful for the rapid isolation of different genes encoding for other sugar phosphorylating or hydrolytic enzymes from a variety of organisms without previous knowledge of amino acid sequences of the corresponding proteins.

Study on LG kinase and its gene is potentially useful because levoglucosan can be prepared in a large scale from ubiquitous cellulosic materials by fast pyrolysis techniques. Furthermore, LG kinase's high $K_{\mathrm{m}}$ value for levoglucosan suggests that the enzyme has been evolved from an existing protein. Therefore, the nature of this enzyme is also interesting in terms of the evolution and adaptation of microorganisms.

\section{References}

[1] J.J. Schauer, M.J. Kleeman, G.R. Cass, B.R. Simoneit, Measurement of emissions from air pollution sources. 3. C1-C29 organic compounds from fireplace combustion of wood, Environ. Sci. Technol. 35 (9) (2001) 1716-1728.

[2] C.G. Nolte, J.J. Schauer, G.R. Cass, B.R. Simoneit, Highly polar organic compounds present in wood smoke and in the ambient atmosphere, Environ. Sci. Technol. 35 (10) (2001) 1912-1919.

[3] P.M. Fine, G.R. Cass, B.R. Simoneit, Chemical characterization of fine particle emissions from fireplace combustion of woods grown in the northeastern United States, Environ. Sci. Technol. 35 (13) (2001) 2665-2675.

[4] M.D. Guillen, M.J. Manzanos, M.L. Ibargoitia, Carbohydrate and nitrogenated compounds in liquid smoke flavorings, J. Agric. Food. Chem. 49 (5) (2001) 2395-2403.

[5] J.H. Pazur, Y. Tominaga, C.W. DeBrosse, L.M. Jackman, The synthesis of 1,6-anhydro- $\beta$-D-glucopyranose and D-glucosyl oligosaccharides from maltose by a fungal glucosyltransferase, Carbohydr. Res. 61 (1978) 279-290.

[6] L. Dorland, S.K. Wadman, H. Fabery de Jonge, D. Ketting, 1,6Anhydro- $\beta$-D-glucopyranose ( $\beta$-glucosan), a constituent of human urine, Clin. Chim. Acta 159 (1) (1986) 11-16.

[7] Y. Nishi, Y. Miyakawa, K. Kato, Chromosome aberrations induced by pyrolysates of carbohydrates in Chinese hamster v79 cells, Mutat. Res. 227 (2) (1989) 117-123.

[8] K.M. Belyk, W.R. Leonard Jr., D.R. Bender, D.L. Hughes, Practical synthesis of 1,6-anhydro-2,4-dideoxy- $\beta$-D-glycero-hexopyranos-3-ulose from levoglucosan, J. Org. Chem. 65 (8) (2000) 2588-2590

[9] I.A. Wolff, D.W. Olds, P. Ill, Levoglucosan production by pyrolysis of pretreated starches, 1969, US Patent, No. 3478012.

[10] V.A. Zubkov, R.P. Gorshkova, Y.S. Ovodor, A.F. Sviridov, A.S. Shashkov, Synthesis of 3,6-dideoxy-4-C-(4C1)-hydroxyethyl) hexopyranoses (yersinioses) from 1,6-anhydro- $\beta$-D-glucopyranose, Carbohydr. Res. 225 (2) (1992) 189-207.

[11] N.K. Kochetkov, D.V. Yashunsky, A.F. Sviridov, M.S. Ermolenko, Stereocontrolled synthesis of lankanolide from 1,6anhydro- $\beta$-D-glucopyranose (levoglucosan). 1 , synthesis of the C$1 / 7$ and C-8/15 segments, Carbohydr. Res. 200 (1990) 209-225.

[12] D. Radlein, J. Piskorz, D.S. Scott, Fast pyrolysis of natural polysaccharides as a potential industrial process, J. Anal. Appl. Pyrol. 19 (1991) 41-63.
[13] J. Piskorz, D. Radlein, D.S. Scott, S. Czernik, Pretreatment of wood and cellulose for production of sugars by fast pyrolysis, J. Anal. Appl. Pyrol. 16 (1989) 127-136.

[14] M. Nakagawa, Y. Sakai, T. Yasui, Itaconic acid fermentation of levoglucosan, J. Ferment. Technol. 62 (1984) 201-203.

[15] E.M. Prosen, D. Radlein, J. Piskorz, D.S. Scott, R.L. Legge, Microbial utilization of levoglucosan in wood pyrolysate as a carbon and energy source, Biotechnol. Bioeng. 42 (1993) 538-541.

[16] X.L. Zhuang, H.X. Zhang, J.Z. Yang, H.Y. Qi, Preparation of levoglucosan by pyrolysis of cellulose and its citric acid fermentation, Bioresour. Technol. 79 (2001) 63-66.

[17] Y. Kitamura, Y. Abe, T. Yasui, Metabolism of levoglucosan (1,6anhydro- $\beta$-D-glucopyranose) in microorganism, Agric. Biol. Chem. 55 (2) (1991) 515-521.

[18] Y. Kitamura, T. Yasui, Purification and some properties of levoglucosan (1,6-anhydro-D-glucopyranose) kinase from the yeast Sporobolomyces salmonicolor, Agric. Biol. Chem. 55 (2) (1991) 523-529.

[19] T. Yasui, Y. Kitamura, K. Nakahara, Y. Abe, Meatbolism of levoglucosan (1,6-anhydro- $\beta$-D-glucopyranose) in bacteria, Agric. Biol. Chem. 55 (7) (1991) 1927-1929.

[20] K. Nakahara, Y. Kitamura, Y. Yamagishi, H. Shoun, T. Yasui, Levoglucosan dehydrogenase involved in the assimilation of levoglucosan in Arthrobacter sp. I-552, Biosci. Biotech. Biochem. 58 (12) (1994) 2193-2196.

[21] X.L. Zhuang, H.X. Zhang, J.J. Tang, Levoglucosan kinase involved in citric acid fermentation by Aspergillus niger $C B X$ 209 using levoglucosan as sole carbon and energy source, Biomass Bioenergy 21 (1) (2001) 53-60.

[22] J. Sambrook, E.F. Fritsch, T. Maniatis, Molecular Cloning: A Laboratory Manual, second ed., Cold Spring Harbor laboratory Press, Cold Spring Harbor, NY, 1989.

[23] R.W. Davis, D. Botstein, J.R. Roth, in: Advanced Bacterial Genetics-A Manual for Genetic Engineering, ColdSpring Harbor Laboratory Press, Cold Spring Harbor, NY, 1980, pp. 13-19.

[24] M. Hirai, E. Ohtani, A. Tanaka, S. Fukui, Glucose-phosphorylating enzymes of Candida yeasts and their regulation in vivo, Biochim. Biophys. Acta 480 (1977) 357-366.

[25] M.M. Bradford, A rapid and sensitive method for the quantitation of microgram quantities of protein utilizing the principle of protein-dye binding, Anal. Biochem. 72 (1976) 248-254.

[26] U.K. Laemmli, Cleavage of structural proteins during the assembly of the head of bacteriophage T4, Nature 227 (1970) 680-685.

[27] P. Chomczynski, A reagent for the single-step simultaneous isolation of RNA and proteins from cell and tissue samples, Biotechniques 15 (3) (1993) 532-535.

[28] P. Chomczynski, N. Sacchi, Single-step method of RNA isolation by acid guanidinium thiocyanate-phenol-chloroform extraction, Anal. Biochem. 162 (1987) 156-159.

[29] H. Okayama, P. Berg, High-efficiency cloning of full-length cDNA, Mol. Cell. Biol. 2 (1982) 161-170.

[30] U. Gubler, B.J. Hoffman, A simple and very efficient method for generating cDNA libraries, Gene 25 (2-3) (1983) 263-269.

[31] A. Ullrich, J. Shine, J. Cirgwin, R. Pictet, E. Tischer, W.J. Rutter, H.M. Goodman, Rat insulin genes: construction of plasmids containing the coding sequences, Science 196 (1977) 1313-1319.

[32] E.M. Lederberg, S.N. Cohen, Transformation of Salmonella typhimurium by plasmid deoxyribonucleic acid, J. Bacteriol. 119 (1974) 1072-1074.

[33] I.H. Fine, L.A. Costello, in: S.P. Colowick, N.O. Kaplan (Eds.), Methods in Enzymology, vol. 6, Academic Press, New York, 1963, p. 958.

[34] M.Y. Kamel, D.P. Allison, R.L. Anderson, Stereospecific Dglucokinase of Aerobacter aerogenes purification and properties, J. Biol. Chem. 241 (3) (1966) 690-694. 
[35] M.J. Parry, D.G. Walker, Purification and properties of adenosine 5 '-triphospae-D-glucose 6-phosphotransferase from rat liver, Biochem. J. 99 (2) (1966) 266-274.

[36] D.H. Williams, G. Bojesen, A.D. Auffret, L.C. Taylor, Study of 'difficult peptides' from Paracoccus cytochrome c-550 and a dolphin cytochrome c. Fast atom bombardment: a new method for molecular weight and sequence determination of peptides, FEBS Lett. 128 (1) (1981) 37-39.

[37] H. Aviv, P. Leder, Purification of biologically active globin messenger RNA by chromatography on oligo-thymidylic acidcellulose, Proc. Natl. Acad. Sci. USA. 69 (6) (1972) 14081412.

[38] S.N. Cohen, A.C.Y. Chang, L. Hsu, Nonchromosamal antibiotic resistance in bacteria: Genetic transformation of Escherichia coli by R-factor DNA, Proc. Natl. Acad. Sci. USA. 69 (8) (1972) 2110-2114.

[39] D.H. Figurski, D.R. Helinski, Replication of an origin-containing derivative of plasmid RK2 dependent on a plasmid function provided in trans, Proc. Natl. Acad. Sci. USA 76 (4) (1979) 16481652.

[40] M. Barbar, R.S. Bordoli, R.D. Sedgwick, A.N. Tyler, B.W. Bycroft, Fast atom bombardment mass spectrometry on bleomycin $\mathrm{A} 2$ and $\mathrm{B} 2$ and their metal complexes, Biochem. Biophys. Res. Commun. 101 (2) (1981) 632-638.

[41] B. Domon, C.E. Costello, Structure elucidation of glycosphingolipids and gangliosides using high-performance tandem mass spectrometry, Biochemistry 27 (5) (1988) 1534-1543.

[42] C. Coulombel, M.J. Foglietti, F. Percheron, Identification and kinetic studies of an inducible mannokinase from a Streptomyces strain, Biochim. Biophys. Acta 706 (1) (1982) 117-122.

[43] A. Bhatnagar, B. Das, S.R. Gavva, P.F. Cook, S.K. Srivastava, The kinetic mechanism of human placental aldose reductase and aldehyde reductase II, Arch. Biochem. Biophys. 261 (2) (1988) 264-274.

[44] W.E. DeWolf Jr., F.A. Emig, V.L. Schramm, AMP nucleosidase: kinetic mechanism and thermodynamics, Biochemistry 25 (14) (1986) 4132-4140.

[45] E.A. Barnard, A.C. Chou, J.E. Wilson, in: W.A. Wood (Ed.), Methods in Enzymology, vol. 42, Academic Press, New York, 1975, pp. 6-25.

[46] R.L. Printz, M.A. Magnuson, D.K. Granner, Mammalian glucokinase, Annu. Rev. Nutr. 13 (1993) 463-496.
[47] E. van Schaftingen, M. Detheux, M. Veiga da Cunha, Short-term control of glucokinase activity: role of a regulatory protein, FASEB J. 8 (6) (1994) 414-419.

[48] H. Heimberg, A. De Vos, K. Moens, E. Quartier, L. Bouwens, D. Pipeleers, E. van Schaftingen, O. Madsen, F. Schuit, The glucose sensor protein glucokinase is expressed in glucagon-producing alpha-cells, Proc. Natl. Acad. Sci. USA. 93 (14) (1996) 7036-7041.

[49] H. Panneman, G.J. Ruijter, H.C. van den Broeck, E.T. Driever, J. Visser, Cloning and biochemical characterization of an Aspergillus niger glucokinase. Evidence for the presence of separate glucokinase and hexokinase enzymes, Eur. J. Biochem. 240 (3) (1996) $518-525$.

[50] H. Panneman, G.J. Ruijter, H.C. van den Broeck, J. Visser, Cloning and biochemical characterization of Aspergillus niger hexokinase-the enzyme is strongly inhibited by physiological concentrations of trehalose 6-phosphate, Eur. J. Biochem. 258 (1) (1998) 223-232.

[51] G.P. Hazlewood, H.J. Gilbert, Structure and function analysis of Pseudomonas plant cell wall hydrolases, Prog. Nucleic. Acid. Res. Mol. Biol. 61 (1998) 211-241.

[52] S. Ito, Alkaline cellulases from alkaliphilic Bacillus: enzymatic properties, genetics, and application to detergents, Extremophiles 1 (2) (1997) 61-66

[53] D.B. Wilson, Biochemistry and genetics of actinomycete cellulases, Crit. Rev. Biotechnol. 12 (1-2) (1992) 45-63.

[54] A. Saloheimo, B. Henrissat, A.M. Hoffren, O. Teleman, M. Penttila, A novel, small endoglucanase gene, egl5, from Trichoderma reesei isolated by expression yeast, Mol. Microbiol. 13 (2) (1994) 219-228.

[55] R.B. Ward, Levoglucosan, in: R.L. Whistler, M.L. Wolfrom, J.M. BeMiller (Eds.), Methods in Carbohydrate Chemistry, Academic Press, New York, 1963, pp. 394-396.

[56] G.P. Xue, C.G. Orpin, K.S. Gobius, J.H. Aylward, G.D. Simpson, Cloning and expression of multiple cellulase cDNAs from the anaerobic rumen fungus Neocallimastix patriciarum in Escherichia coli, J. Gen. Microbiol. 138 (7) (1992) 1413-1420.

[57] C.H. Chang, S. Cha, R.W. Brockman, L.L. Bennett Jr., Kinetic studies of adenosine kinase from L1210 cells: a model enzyme with a two-site ping-pong mechanism, Biochemistry 22 (3) (1983) 600-611.

[58] E. Tryon, S.A. Kuby, Studies on NADPH-cytochrome c reductase. II. Steady-state kinetic properties of the crystalline enzyme from ale yeast, Enzyme 31 (4) (1984) 197-208. 